\title{
RUANG TERBUKA SEBAGAI GAYA HIDUP TERKAIT KESEHATAN DAN PERAN KAWASAN HUNIAN KOTA
}

\author{
Indah Yuliasari \\ Universitas Indraprasta PGRI, Program Studi Arsitektur \\ yuliasari.wibowo@gmail.com
}

\begin{tabular}{ll}
\hline Informasi artikel \\
\hline Sejarah & \\
artikel: & \\
Diterima & 17 Agustus 2021 \\
Revisi & 23 September 2021 \\
Dipublikasikan & 30 September 2021 \\
\hline
\end{tabular}

\section{ABSTRAK}

Penelitian yang dilaporkan dalam makalah ini membahas hubungan antara kualitas ruang terbuka dan gaya hidup terkait kesehatan di kawasan pemukiman perkotaan. Penelitian ini dilakukan di pembangunan perumahan Deltasari di kota Sidoarjo, yang dimulai dari masa perubahan politik dan ekonomi di awal tahun sembilan puluhan. Dibandingkan dengan lingkungan yang lebih tua, ini

Kata kunci: biasanya merupakan area perumahan sekali pakai, dengan ruang terbuka kecil kawasan hijau kesehatan dan desain lansekap yang buruk. Penelitian ini berkaitan dengan kualitas hidup di daerah-daerah, terutama dari perspektif pengguna yang rentan, seperti orang tua dan anak-anak. Keduanya bergantung pada area hijau yang mudah diakses di dekat rumah mereka. Hipotesisnya adalah bahwa kualitas ruang terbuka yang buruk mempengaruhi perilaku yang berhubungan dengan kesehatan dan status kesehatan yang mereka rasakan. Penelitian ini memiliki tiga tahapan metodologis: perbandingan kawasan permukiman perkotaan dengan kriteria yang menggambarkan karakteristik fisiknya, observasi dan pemetaan perilaku dan survei opini penduduk. Hasilnya mengkonfirmasi perbedaan antara ruang terbuka di area perumahan yang dipilih serta hubungannya dengan kegiatan di luar ruangan, kurangnya program luar ruangan berkorelasi dengan beragamnya kegiatan di luar ruangan, terbatas pada jenis transisi, lebih sedikit waktu yang dihabiskan di luar ruangan dan kepuasan yang lebih rendah dengan lingkungan rumah mereka. Survei dan hasil hipotesis tersebut juga mengungkapkan pengaruh yang kuat dari serangkaian variabel sosial ekonomi seperti pendidikan dan status ekonomi pada aktivitas fisik dan status kesehatan seseorang.

Key word: green area health lifestyle

ABSTRACT
This The research reported in this paper discusses the relationship between the
quality of open space and health-related lifestyles in urban residential areas. This
research was conducted at the Deltasari housing development in the city of
Sidoarjo, which began during a period of political and economic change in the early
nineties. Compared to older neighborhoods, these are typically single-use
residential areas, with little open space and poor landscape design. This study
deals with the quality of life in these areas, especially from the perspective of
vulnerable users, such as the elderly and children. Both rely on easily accessible
green areas near their homes. The hypothesis is that the poor quality of open space
affects their health-related behavior and perceived health status. This research has
three methodological stages: comparison of urban settlement areas with criteria
that describe their physical characteristics, observation and mapping of behavior
and survey of population opinions. The results confirmed the difference between
open space in selected residential areas and their relationship to outdoor
activities, lack of outdoor programs correlated with variety of outdoor activities,
limited transition type, less time spent outdoors and lower satisfaction with their
home environment. The survey and the hypothesized results also reveal the strong
influence of a range of socioeconomic variables such as education and economic
status on a person's physical activity and health status.

\section{PENDAHULUAN}

Semakin diakui bahwa tempat dan ruang berdampak pada kesehatan dan kesejahteraan manusia dan bahwa gaya hidup individu yang berhubungan dengan kesehatan cenderung dipengaruhi oleh lingkungan mereka. Seiring dengan peningkatan jumlah penduduk perkotaan, fokus penelitian di lapangan telah bergeser ke kualitas lingkungan perkotaan. Menurut Organisasi Kesehatan Dunia kondisi kehidupan di lingkungan perkotaan adalah kunci kesehatan dan kesejahteraan penghuninya. 
Bukti dari literatur secara konsisten menunjukkan bahwa ada hubungan antara lingkungan binaan, kesehatan dan kesejahteraan dan tingkat aktivitas fisik.

Kurangnya dan buruknya kualitas ruang terbuka maupun kawasan hijau di lingkungan perkotaan dapat menjadi hambatan serius bagi kesejahteraan penduduk karena tidak mendukung pengembangan gaya hidup sehat, termasuk menghabiskan waktu di luar rumah, berjalan kaki, bermain. Hariyono, Paulus.(2007:73)

Menghabiskan waktu di luar ruangan penting mengurangi paparan udara dalam ruangan, yang sering tercemar oleh penggunaan bahan buatan yang berbeda. Ada juga hubungan yang dikonfirmasi antara menghabiskan waktu di luar ruangan dan berbagai penyakit kronis termasuk obesitas, diabetes tipe II, tekanan darah tinggi, penyakit koroner, asma, nyeri punggung dan sendi.

Penelitian ini juga menunjukkan respon yang tinggi dari warga ketika ditawarkan kawasan terbuka hijau yang mudah diakses dan berkualitas. Dalam keadaan seperti itu, orang cenderung menghabiskan lebih banyak waktu di luar ruangan, yang memiliki efek positif pada harapan hidup, kesehatan, kebahagiaan dan kesejahteraan umum, yang tercermin dalam efisiensi individu dan seluruh masyarakat. Aksesibilitas terhadap ruang terbuka dan hijau di lingkungan mereka sangat penting terutama bagi kelompok pengguna tertentu seperti orang tua, anak-anak, ibu dengan bayi, dan penyandang disabilitas. Ketersediaan langsung ruang terbuka hijau yang aman mendukung perkembangan fisik dan psikologis anak yang lebih sehat. Budiharjo, E.(1999:45).

Bukti menunjukkan bahwa anak-anak yang memiliki akses yang lebih baik ke tempat-tempat seperti itu lebih cenderung aktif secara fisik, dan lebih kecil kemungkinannya untuk kelebihan berat badan, dibandingkan dengan mereka yang tinggal di lingkungan dengan akses yang terbatas ke fasilitas tersebut. Hal ini memiliki efek jangka panjang karena ada korelasi langsung antara pemanfaatan ruang terbuka hijau di masa kanak-kanak dengan keadaan kesehatan dan kebiasaan gaya hidup di masa dewasa. Memiliki kontak langsung dengan alam cenderung menjadi tantangan besar bagi anak-anak yang tumbuh di perkotaan. Akses ke ruang hijau juga dikaitkan dengan umur panjang yang lebih besar pada orang tua. Area hijau lanskap perumahan sangat penting bagi pengguna yang rentan, dan tidak dapat diharapkan untuk digantikan oleh ruang hijau yang ditemukan di tempat lain di kota. Lingkungan yang cocok untuk kelompok rentan adalah juga lebih menarik bagi semua pengguna. Oleh karena itu, kriteria kelompok rentan semakin diterapkan dalam perencanaan dan desain kota.

Perbandingan dengan beberapa kawasan perumahan yang lebih tua di Deltasari Sidoarjo menunjukkan bahwa ini secara signifikan direncanakan lebih baik dalam hal area terbuka hijau. Konsep kawasan perumahan dari tahun 1990-an jelas terstruktur, multifungsi dan terutama berorientasi sosial. Paradigma "densifikasi perkotaan", yang telah berlaku dalam kebijakan perencanaan kota sejak awal milenium, dikombinasikan dengan kekurangan perumahan dan harganya yang tinggi mengakibatkan lingkungan perumahan kolektif dengan ruang terbuka dan hijau yang sangat terbatas dan tidak dilengkapi dengan baik. Ditambah dengan ketidakjelasan standar dan pedoman untuk ruang terbuka, hal ini mengakibatkan rendahnya kualitas pembangunan perumahan baru, kurangnya ruang terbuka komunal untuk menampung kegiatan di luar ruangan. Ruang publik adalah ruang yang berfungsi untuk tempat menampung aktivitas masyarakat, baik secara individu maupun secara kelompok, dimana bentuk ruang publik ini sangat tergantung pada pola dan susunan massa bangunan Rustam Hakim(1987:101). Tipologi ruang publik penekanan kepada karakter kegiatannya, lokasi dan proses pembentuknya. Carr dkk (1992:46)

Tujuan dari penelitian yang disajikan dalam makalah ini adalah untuk mengumpulkan bukti empiris tentang kualitas ruang terbuka di lingkungan yang baru dibangun ini dan untuk 
mengungkapkan kurangnya hubungan antara aktivitas di luar ruangan dan gaya hidup yang diadopsi oleh penduduk. Diasumsikan bahwa kualitas yang buruk dan kurangnya area terbuka hijau menyebabkan bentuk pemanfaatan ruang yang buruk dan akibatnya pada gaya hidup yang kurang sehat dibandingkan dengan area dengan kualitas area terbuka yang lebih baik. Gaya perilaku warga digunakan sebagai indikator risiko kesehatan dalam kerangka kesehatan masyarakat,Andress,L(2009:37).

Pendekatan interdisipliner diadopsi, menggabungkan bidang perencanaan kota dengan ilmu kesehatan masyarakat, dan membangun hubungan intrinsik antara kesehatan dan perencanaan dari abad ke-19, ketika perencanaan terutama ditujukan untuk peningkatan kondisi kesehatan di kota-kota industri . Perencanaan kota adalah salah satu penentu protokol kesehatan yang utama, di mana lingkungan adalah blok bangunan dasar di dalam kota

\section{METODOLOGI}

Metodologi penelitian yang diadopsi dibagi dalam tiga tahap sesuai dengan teknik pengumpulan informasi. Peneliti melakukan proses pencarian isu terhangat terkait ruang publik, kesehatan dan gaya hidup masyarakat dikota besar, dan kemudian ditemukannya kata terkait kualitas ruang terbuka dan gaya hidup yang pada akhirnya membuat peneliti tertarik untuk mengangkat penelitian terkait kualitas ruang terbuka dan gaya hidup masyarakat dikota besar, hal ini dilakukan peneliti dalam kurun waktu lebih kurang 3 bulan yaitu mulai dari bulan Januari 2021 sampai dengan bulan Maret2021 dan pengumpulan data penelitian seperti wawancara secara daring serta penyebaran kuesioner secara online dilanjutkan pada bulan April 2021 sampai dengan Mei 2021.Tujuannya adalah untuk menjawab pertanyaan-pertanyaan berikut: seperti apa desain perkotaan kawasan hunian? Berapa banyak ruang terbuka hijau yang ada di daerah tersebut? Apakah ruang terbuka di kawasan pemukiman mengakomodasi berbagai penggunaan lahan dan kegiatan sesuai dengan kebutuhan yang beragam dari kelompok umur yang berbeda?. Walaupun pemakaian jumlah sampel yang besar sangat dianjurkan, dengan pertimbangan adanya berbagai keterbatasan pada peneliti, sehingga peneliti berusaha mengambil sampel minimal dengan syarat dan aturan statistika tetap terpenuhi sebagaimana dianjurkan oleh Isaac dan Michael (Sukardi, 2004:55).

1. Fase metodologis pertama, sehubungan dengan pertanyaan berikut, apa yang sebenarnya dilakukan orang di ruang terbuka perumahan?

2. Fase metodologis kedua,bagaimana pendapat warga tentang tempat tinggalnya? Bagaimana mereka melihatnya? Bagaimana perasaan mereka di sana? Apa gaya hidup mereka? Bagaimana mereka menilai kesejahteraan dan status kesehatan mereka.

3. Fase metodologis ketiga, setiap fase metodologis mengeksplorasi lapisan ruang tertentu, fase pertama menggambarkan kualitas fisik, fase kedua menangani aspek perilaku sosial, dan fase ketiga menyelidiki lapisan perseptifnya.

Penelitian dibatasi pada kawasan permukiman di Deltasari Sidoarjo untuk mengontrol parameter makro lokasi, seperti akses pelayanan dan kawasan terbuka hijau di pusat kota dan latar belakangnya. Tahap pertama melibatkan deskripsi dan evaluasi desain ruang terbuka menurut seperangkat kriteria pembangunan kota. 


\section{POPULASI DAN SAMPEL}

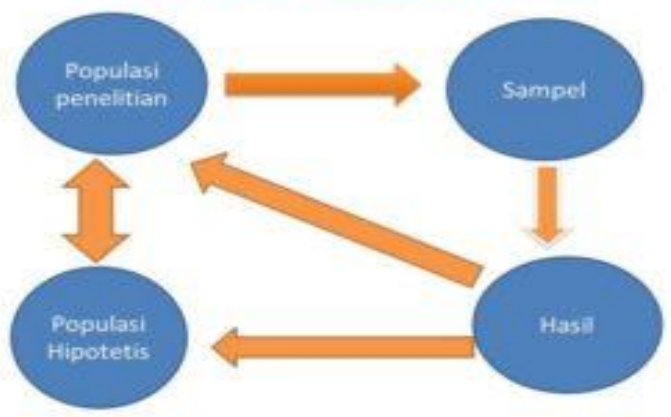

Gambar 1. Populasi dan Sampel

Nilai yang dihitung dan diperoleh dari populasi ini disebut dengan parameter. Populasi merupakan seluruh jumlah dari subjek yang akan diteliti oleh seorang peneliti. Menurut Arikunto Suharsimi (1998: 117), Populasi adalah keseluruhan objek penelitian. Apabila seseorang ingin meneliti sebuah elemen yang ada dalam wilayah penelitian tersebut, maka penelitiannya merupakan penelitian populasi. Adapun untuk sampel adalah bagian dari populasi yang memiliki karakteristik mirip dengan populasi itu sendiri. Arikunto (2006: 131), Sampel adalah sebagian atau sebagai wakil populasi yang akan diteliti. Jika penelitian yang dilakukan sebagian dari populasi maka bisa dikatakan bahwa penelitian tersebut adalah penelitian sampel. Sugiyono (2008: 118), sampel adalah suatu bagian dari keseluruhan serta karakteristik yang dimiliki oleh sebuah populasi.

Aspek spasial, demografi, dan sosial ekonomi dipertimbangkan karena ketiganya berkaitan erat dengan gaya hidup, yang dapat bermanfaat atau merugikan kesehatan secara umum. Indikator utama kualitas lingkungan perkotaan pada tingkat lingkungan terkait dengan kepadatan hunian, keragaman penggunaan lahan, aksesibilitas pelayanan, kesempatan berjalan kaki dan bersepeda, ruang terbuka hijau perkotaan, ruang aman untuk bermain anak, untuk duduk dan bersosialisasi. Kriteria demografi meliputi struktur umur penduduk, sedangkan kriteria sosial ekonomi adalah status pekerjaan dan tingkat pendidikan. Setiap kriteria dialokasikan satu set indikator, dievaluasi secara individual untuk setiap area perumahan dengan mengacu pada nilai yang ditentukan atau yang direkomendasikan. Deskripsi ini digunakan untuk perbandingan antara daerah yang lebih tua dan yang lebih baru, dan untuk pemilihan daerah untuk studi lebih lanjut. Karena fokus penelitian adalah kompleks perumahan baru, kami memasukkan keempatnya ke dalam studi lebih lanjut.

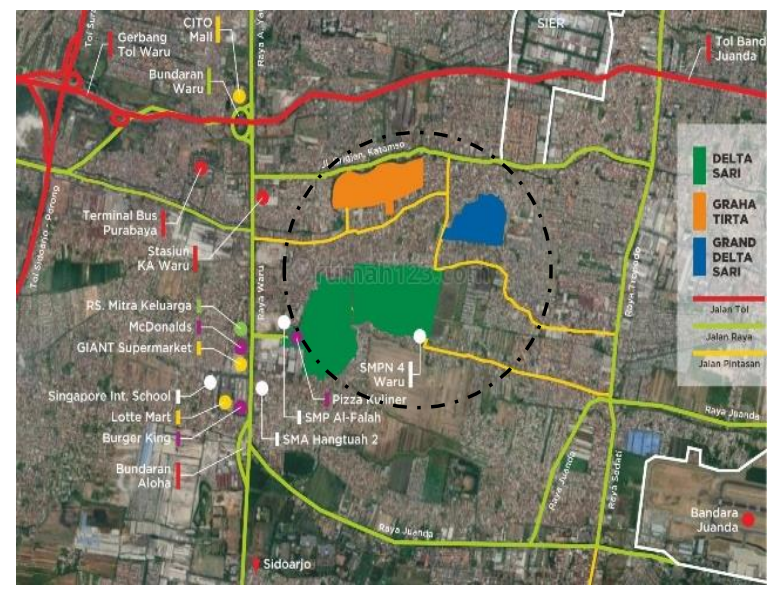

Gambar 2. Lokasi kawasan pemukiman di Deltasari Sidoarjo, termasuk dalam penelitian tahap metodologis pertama 
Daerah pemukiman yang termasuk dalam bagian tindak lanjut dari studi, juga diilustrasikan dalam diagram yang menunjukkan garis besar area, peta skema dengan kunci peta, dan foto daerah.

Tahap kedua penelitian melibatkan pengamatan perilaku dan pemetaan. Ini adalah salah satu metode yang paling umum digunakan dalam penelitian ruang terbuka perkotaan. Psikologi lingkungan mendefinisikan beberapa jenis peta perilaku mereka bisa berupa matriks atau peta perilaku dalam arti kata yang sebenarnya. Untuk tujuan penelitian ini, matriks perilaku dan peta digunakan yang pertama berfungsi sebagai alat deskripsi kuantitatif kegiatan individu, sedangkan yang kedua menunjukkan korelasi antara struktur ruang dan penggunaannya. Sebelum dimulainya kerja lapangan, sistem pengkodean untuk merekam kegiatan tertentu ditentukan berdasarkan daftar kegiatan yang dapat diprediksi sebelumnya. Jenis kegiatan yang tidak terduga atau sangat spesifik dapat ditambahkan di tempat. Sebuah jadwal ditetapkan dengan tiga periode waktu dalam sehari (dari jam 10 pagi sampai 12 siang, dari jam 1 siang sampai jam 3 sore, dan dari jam 5 sore sampai jam 7 malam). Periode waktu ini dipilih untuk memasukkan variabilitas tertinggi pengguna. Daerah pemukiman dibagi menjadi unit pengamatan, yang dapat dipantau dalam satu pandangan pengamat.

Setiap sub-area kemudian diamati sepuluh menit dalam setiap periode waktu. Pengamatan sepuluh hari dilakukan dalam waktu tiga minggu, termasuk akhir pekan. Pengamat ditunjuk untuk menggunakan penelitian observasi metode, satu pengamat per wilayah pemukiman dalam setiap periode waktu, yang mencakup semua subarea dalam satu wilayah pemukiman individu. Semua kawasan pemukiman terpilih diamati pada waktu yang sama, sehingga hasilnya menunjukkan perbandingan ruang dan waktu.

Observasi dan pemetaan perilaku merupakan sebuah metode untuk penelitian ruang terbuka publik perkotaan. Observasi lapangan dilanjutkan dengan transfer data ke dalam Sistem Informasi Geografis dan klasifikasi kategori parameter. Setiap input data dari aktivitas yang diamati dari satu orang dijelaskan dengan parameter dalam kategori berikut: jenis kelamin, aktivitas, jenis aktivitas, kategori aktivitas, usia, durasi, waktu, bagian dalam seminggu, suhu, angin, udara kelembaban, langit cerah atau mendung, dan tanggal. Aktivitas adalah kategori deskriptif, yang menjelaskan tindakan secara lebih rinci, sedangkan Jenis Aktivitas memberikan deskripsi terperinci ke kelas terdekat, misalnya, berjalan, bermain, penitipan anak, menghabiskan waktu di luar ruangan, Thompson,(2007:135).

Mengelompokkan semua aktivitas berbeda yang diamati selama penelitian lapangan ke dalam salah satu dari empat kelas umum: pasif dalam ruang, aktif dalam perjalanan, aktif dalam ruang, pasif sesaat. Kuesioner disiapkan untuk memahami pengalaman subjektif lingkungan perumahan dari perspektif penghuni dan gaya perilaku terkait kesehatan mereka. Struktur kuesioner dibagi menjadi dua bagian, dan sebagian besar terdiri dari pertanyaan tertutup. Ini termasuk evaluasi diri kesehatan, penilaian aktivitas fisik waktu luang, sikap merokok dan evaluasi diri kesehatan anak-anak. Pertanyaan mengenai area perumahan diambil dari penelitian termasuk pertanyaan tentang status kepemilikan, ukuran properti, akses ke layanan, alasan tinggal di area perumahan tertentu, kepuasan dengan properti dan area, persepsi keterbukaan ruang dan suasana keseluruhan di area tersebut (kontak dengan tetangga, keterikatan dengan area).

Kuesioner juga mencakup pertanyaan yang mengacu pada penggunaan ruang terbuka dalam gaya hidup mereka. Data demografi tentang jenis kelamin, usia, tingkat pendidikan dan pendapatan, jumlah anak dan orang tua yang tinggal dalam rumah tangga yang sama, dan status pekerjaan juga dikumpulkan. Orang-orang yang termasuk dalam survei berusia 18 tahun ke atas. Alasan yang diketahui 
untuk non-responsif termasuk kurangnya waktu, keengganan untuk mengambil bagian dan suasana hati yang buruk, skeptisisme tentang manfaat dari survei semacam itu.

\section{HASIL DAN PEMBAHASAN}

Gambaran kawasan pemukiman terpilih menunjukkan bahwa kompleks perumahan baru berukuran jauh lebih kecil, yang merupakan yang terkecil dari empat kawasan perumahan lama. Yang terakhir termasuk toko lokal, fasilitas pertemuan masyarakat dan pembibitan dengan area terbukanya sendiri, sebagai bagian dari layanan perumahan dasar. Rasio plot lebih tinggi di kompleks perumahan baru di Deltasari Sidoarjo. Deskripsi dan evaluasi kawasan hunian terpilih untuk tujuan penelitian ini, area penggunaan aktif dihitung tidak termasuk area pribadi, tempat parkir dan jalan, dan area penggunaan pasif (pribadi). Area hijau yang digunakan secara aktif dianggap sebagai area yang secara substansial berkontribusi pada kualitas hidup secara keseluruhan dan sama-sama dapat diakses oleh semua penduduk.

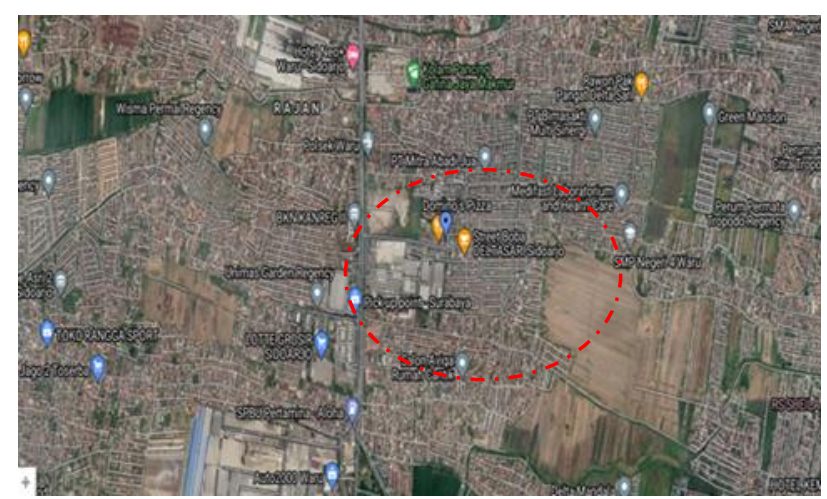

Gambar 3. Evaluasi area pemukiman Deltasari Sidoarjo dengan ukuran spasial area terbuka dan hijau, dijelaskan oleh berbagai indikator (semua area terbuka, area fungsional tidak termasuk taman atrium lantai dasar pribadi, jalan dan area parkir mobil eksternal, area pasif atrium, penggunaan pribadi)

Hasil ini memberikan bukti empiris bahwa ruang terbuka di kawasan pemukiman pasca transisi tidak memenuhi standar baik dari segi nilai yang direkomendasikan maupun dalam hal perbandingan dengan contoh lama. Permukiman Deltasari Sidoarjo adalah salah satu contoh praktik yang baik dengan furnitur perkotaan yang serbaguna, area hijau dan area terbuka yang memadai menawarkan berbagai penggunaan dan aktivitas ruang untuk semua kelompok umur. Ada juga perbedaan di antara lingkungan baru secara kualitas dan kuantitas ruang terbuka terbaik.

\section{Pengamatan dan Pemetaan Perilaku}

Penganatan untuk mendapat gambaran pemetaan perilaku di ruang publik adalah melalui pengamatan pada seseorang untuk mengetahui kemana orang tersebut pergi, bagaimana pergerakan mereka dengan pengukuran jejak fisik serta pemetaan perilaku (Sommer,1986) Presentasi grafis pengamatan memungkinkan wawasan penggunaan spasial menurut kategori aktivitas dan kelompok usia.

Secara umum, metode observasi mengungkapkan bahwa semua ruang terbuka di kawasan perumahan baru sebagian besar digunakan oleh pengguna termuda, sementara kurangnya fasilitas untuk kelompok usia lain.

Meskipun furnitur jalan spasial dan fitur lansekap yang buruk dari daerah perumahan yang lebih baru, ada banyak pengguna ruang terbuka yang diamati di daerah ini. Namun, sebagian besar pengguna yang diamati terlibat dalam kegiatan sementara, menunjukkan bahwa ruang terbuka tidak menarik atau bahkan tidak memungkinkan kegiatan menghabiskan lebih banyak waktu di daerah tersebut. 
Berdasarkan pengamatan penggunaan sementara terbatas pada jalan setapak, sementara berbagai kegiatan diamati di berbagai area yang menawarkan kemungkinan (bangku, taman bermain, trampolin, fitur lanskap yang beragam.

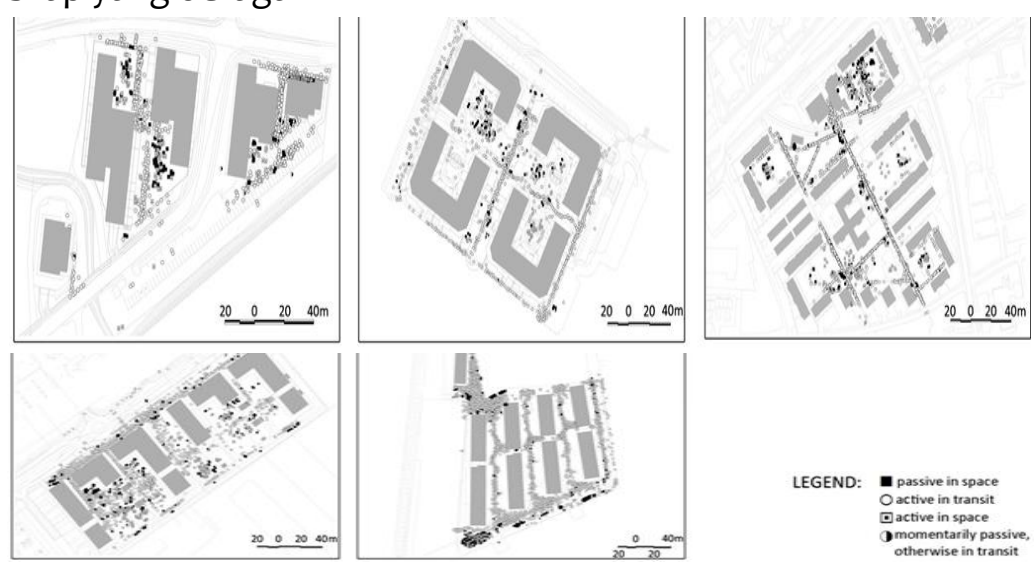

Gambar 4. Hasil observasi dan pemetaan perilaku di Deltasari Sidoarjo menunjukkan kategori hasil observasi dan pemetaan perilaku menunjukkan kategori aktivitas untuk menunjukkan kelompok usia dalam kaitannya dengan aktivitas lain yang diamati dalam waktu yang sama
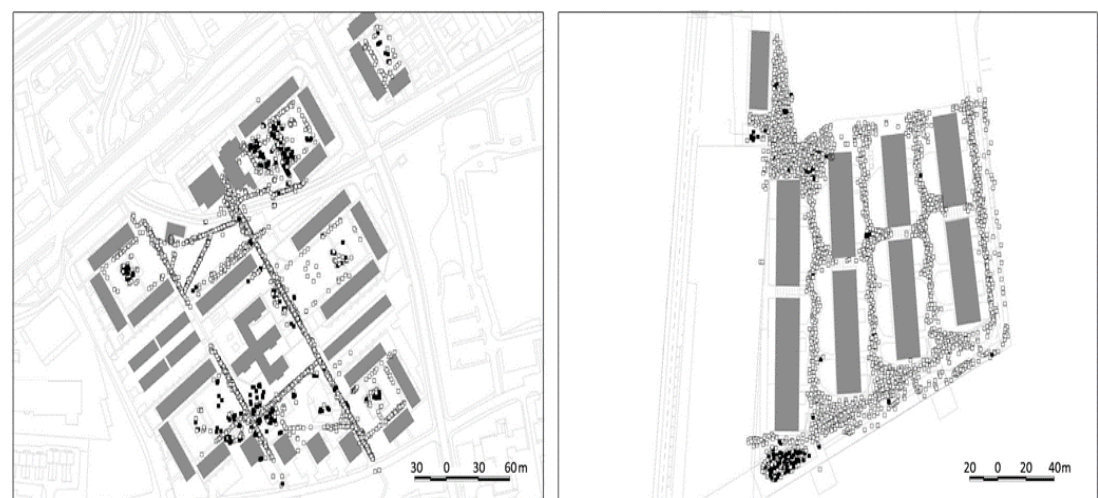

Gambar 5. Penyajian grafik hasil tidak sepenuhnya mengungkapkan semua ragam permainan anak-anak di Deltasari.

Anak-anak yang aktif terdistribusi secara merata di seluruh area terbuka dengan sebagian besar kegiatan bermain anak-anak yang diamati di luar taman bermain, terutama di daerah dengan fitur lanskap yang beragam seperti tepi antara ruang terbuka dan tata ruang luar yang bervariasi. Program yang buruk dan kurangnya area terbuka menyebabkan berkurangnya variasi penggunaan ruang. Secara konseptual, sebuah kegiatan dapat terdiri dari sub-sub kegiatan yang saling berhubungan sehingga terbentuk sitem kegiatan (Rapoport, 1986).

\section{PENUTUP}

Untuk menafsirkan secara komprehensif peran tata ruang luar perumahan dengan fungsi sebagai ruang terbuka untuk gaya hidup penggunanya, penting untuk menghubungkan variabel spasial fisik, sosial dan simbolis, yang mengungkapkan hubungan tak terlihat antara struktur ruang, perilaku dan persepsi. Dengan menyoroti faktor-faktor penentu, yang mempengaruhi gaya hidup terkait kesehatan penghuni, hasil penelitian ini memberikan kontribusi pengetahuan pada hipotesis bahwa kualitas yang buruk dan kurangnya area terbuka hijau menyebabkan bentuk pemanfaatan ruang yang buruk dan akibatnya gaya hidup yang kurang sehat. 
Kepadatan yang berlebihan, kurangnya area terbuka, desain dan furnitur ruang luar yang buruk. Temuan utama mengenai determinan perilaku protokol kesehatan memberikan bukti keterkaitan antara kualitas ruang terbuka dan variasi dan lama penggunaannya.

Di daerah pemukiman dengan ruang terbuka yang tidak memadai dan tidak tertata dengan baik, hal ini menunjukkan bahwa ruang terbuka di kawasan permukiman baru sebagai penentu persepsi kesehatan bersifat tidak langsung dan mempengaruhi pola perilaku penghuni. Pola perilaku terutama keterlibatan dalam aktivitas fisik, evaluasi diri kesehatan dan kepuasan dengan lingkungan hidup sangat berkorelasi dengan status ekonomi dan pendidikan. Giles-Corti(2005, 28, 169-176).

Meskipun penelitian menegaskan hubungan antara penentu spasial, perilaku dan persepsi gaya hidup, itu juga dipengaruhi oleh banyak variabel lainnya. Klaim bahwa penggunaan ruang terbuka yang lebih baik juga mengarah pada gaya hidup yang umumnya lebih sehat dan penilaian kesehatan diri yang lebih baik oleh karena itu tidak dapat sepenuhnya dikonfirmasi. Pengaruh faktor penentu lain seperti status ekonomi, usia dan pendidikan terlalu kuat untuk memungkinkan pernyataan konklusif.

Bagian penelitian telah menunjukkan bahwa kontribusi ruang terbuka terhadap kualitas hidup paling tinggi dalam permukiman di Deltasari Sidoarjo. Ini adalah bukti empiris bahwa kawasan hunian yang lebih tua dan berdesain klasik lebih unggul daripada kawasan baru yang kontemporer. Signifikansi faktor-faktor penentu yang terkait dengan ruang terbuka lebih tinggi bagi penduduk yang termasuk dalam kelompok usia termuda dan tertua dengan pendapatan terendah dan latar belakang pendidikan yang berbeda. Ada implikasi dari temuan ini untuk perencanaan kota dalam perspektif jangka panjang kawasan perumahan, struktur demografi dan sosial mereka pasti berubah.

Lingkungan perumahan tidak hanya dibangun untuk penduduk yang usia produktif saja, yang dapat menjalankan gaya hidup mereka secara mandiri dari lingkungan sekitar mereka, tetapi harus menyediakan lingkungan yang sehat juga untuk kelompok rentan yang gaya hidupnya (dalam kasus anak-anak) atau menilai kesehatan diri sendiri dan kesejahteraan (dalam kasus lansia) juga tergantung pada aktivitas fisik dan sosial yang dilakukan di lingkungan dekat mereka. Semua hasil penelitian ini melebihi cakupan makalah ini oleh karena itu hanya temuan utama yang disajikan.

Penelitian ini menambahkan perspektif kesehatan mendukung pengenalan area hijau di lingkungan sebuah hunian kota. Kualitas ruang terbuka merupakan faktor penting yang memberikan kualitas hidup, baik di daerah yang diregenerasi maupun di pembangunan baru. Profesi perencanaan memiliki salah satu peran utama dalam memastikan kualitas ini, karena rencana tata ruang tidak hanya mempengaruhi parameter fisik tetapi juga sosial dan ekonomi. Area terbuka publik yang dirancang dengan baik meningkatkan nilai properti di sekitarnya hingga $5-7 \%$ dan dengan demikian berhasil menarik investor baru dan pemerintah untuk menyediakan desain perkotaan berkualitas tinggi. Densifikasi pembangunan dengan biaya ruang terbuka adalah tidak dibenarkan secara ekonomi serta tidak masuk akal dari perspektif kesehatan masyarakat, karena membatasi kesempatan untuk gaya hidup aktif secara fisik dan sosial dari sudut pandang perencanaan arsitektur.

\section{DAFTAR PUSTAKA}

Andress, L. Healthy Urban Planning: The Concept, Tools and Application; Center to Eliminate Health Disparities, University of Texas Medical Branch: Galveston, TX, USA, 2009

Amos rapoport. The meaning of the built environment. Beverly hills: sage publications.1986.

Arikunto, Suharsimi. Prosedur Penelitian Suatu Pendekatan Praktek. Jakarta : PT. Rineka Cipta. 1998

Arikunto, Suharsimi. Prosedur Penelitian. Jakarta: PT Rineka Cipta, 2006

Arikunto, Suharsimi. Prosedur Penelitian Suatu Pendekatan Praktik Edisi Revisi. Jakarta: PT. Rineka Cipta.2010 
Budiharjo, E., \& Sujarto, D.1999. Kota yang Berkelanjutan. Bandung: Alumni

Barton, H.; Tsourou, C. Healthy Urban Planning: A WHO Guide to Planning for People; Routledge: New York, NY, USA, 2011

Giles-Corti, B.; Broomhall, M.H.; Knuiman, M.; Collins, C.; Douglas, K.; Ng, K.; Lange, A.; Donovan, R.J. Increasing walking: How important is distance to, attractiveness, and size of public open space? Amer. J. Prev. Med. 2005

Hariyono, Paulus. Sosiologi Kota Untuk Arsitek, Penerbit PT. Bumi Aksara Jakarta, 2007

Holt, N.L.; Spence, J.C.; Sehn, Z.L.; Cutumisu, N. Neighborhood and developmental differences in children's perceptions of opportunities for play and physical activity. Health Place 2008

Hakim,Rustam,Ir.Unsur Dalam Perancangan Arsitektur Landscape. Jakarta: Balai Pustaka,1987

Spencer, C.; Blades, M. Children and Their Environments. Learning, Using and Designing Spaces; Cambridge University Press: Cambridge, UK, 2006

Sommer, Robert, Personal Space: Tthe Behavioral Basis of Design, Eengelwood, Prentice Hall, New York.1969

Sukardi, Metodologi Penelitian Pendidikan: Kompetensi dan Praktiknya, Jakarta: Bumi Aksara,2004

Sugiyono. Metode Penelitian Kuantitatif Kualitatif dan R\&D. Bandung: ALFABETA, 2008

Thompson, C.W.; Travlou, P. Open Space: People Space; Taylor\&Francis Group: Abingdon, London, UK, 2007 